\title{
Effect of Temperature, Vector Life Stage, and Plant Access Period on Transmission of Banana bunchy top virus to Banana
}

\author{
M. D. Anhalt and R. P. P. Almeida
}

First author: Department of Plant and Environmental Protection Sciences, University of Hawaii at Manoa, Honolulu, HI 96822; and second author: Department of Environmental Science, Policy and Management, University of California, Berkeley, CA 94720. Accepted for publication 4 March 2008.

\begin{abstract}
Anhalt, M. D., and Almeida, R. P. P. 2008. Effect of temperature, vector life stage, and plant access period on transmission of Banana bunchy top virus to banana. Phytopathology 98:743-748.

The study of the transmission biology of insect-borne plant viruses is important to develop disease control practices. We characterized the transmission of a nanovirus, Banana bunchy top virus (BBTV), by its aphid vector Pentalonia nigronervosa Coquerel (Hemiptera, Aphididae) with respect to temperature, vector life stage, and plant access time. Adult

efficiency by nymphs. By decoupling the relationship between temperature and aphid BBTV acquisition or inoculation, we determined that temperature affected inoculation events more strongly than acquisition. Longer plant access periods increased viral acquisition and inoculation efficiencies in a range of $60 \mathrm{~min}$ to $24 \mathrm{~h}$. Both BBTV acquisition and inoculation efficiencies peaked after $18 \mathrm{~h}$ of plant access period. We also show that BBTV transmission by $P$. nigronervosa requires a latent period. Our results demonstrate that vector transmission of BBTV is affected by temperature, vector life stage, and plant access period.
\end{abstract} aphids transmitted BBTV more efficiently than third instar nymphs at all temperatures tested. Adult aphids transmitted the virus more efficiently at 25 and $30^{\circ} \mathrm{C}$ than at $20^{\circ} \mathrm{C}$, but temperature had no impact on transmission
Additional keywords: circulative, Nanoviridae.
The majority of plant viruses rely on biological vectors for dissemination, thus these other organisms dramatically affect virus biology, ecology, and epidemiology $(18,19)$. Insects represent the main group of plant virus vectors, with aphids transmitting over $50 \%$ of known viruses (12). Therefore, it is not surprising that aphid-borne viruses are among the better studied systems in relation to transmission biology. Modes of plant virus transmission are classified primarily based on the effect of time on pathogen acquisition and inoculation efficiencies and its persistence within vectors $(18,19)$. The best studied aphid-borne circulative viruses belong to the family Luteoviridae. Various factors affect the transmission of luteoviruses, including aphid life stage, plant access time, host plant, virus strain, and temperature $(9,10,14,20,29)$.

For other virus families, such as the recently established Nanoviridae, a group of small icosahedral multipartite single-stranded (ss)DNA viruses (8), the virus-vector relationships have not been studied in such detail. Like luteoviruses, nanoviruses are transmitted in a circulative, nonpropagative, nontransovarial manner, with an increase in transmission efficiency with increments of acquisition and inoculation plant access time $(6,7,11,17)$. The requirement of a latent period within vectors for transmission has not been demonstrated; presence of a latent period would represent additional biological evidence that these viruses are transmitted in a circulative manner. All nanoviruses are aphid-borne with the exception of Coconut foliar decay virus (CFDV), which is transmitted by cixiid bugs (Myndus taffini) (13). Banana bunchy top virus (BBTV), the only member of the genus Babuvirus (Nanoviridae), is the etiological agent of Banana bunchy top disease (BBTD). BBTV has at least six $\approx 1-\mathrm{kb}$ ssDNA components (2). The only known vector of BBTV is the aphid Pentalonia

Corresponding author: R. P. P. Almeida; E-mail address: rodrigo@ nature.berkeley.edu

doi:10.1094/PHYTO-98-6-0743

(c) 2008 The American Phytopathological Society nigronervosa Coquerel (Hemiptera, Aphididae) (5). BBTV infects plants in the Musaceae and is a major pathogen of bananas in Hawaii, islands in the south Pacific and southeast Asia (5).

Vector life stage affects pathogen transmission efficiency in many systems. Tomato spotted wilt virus (TSWV) transmission by thrips, where acquisition must occur during the first larval stage, is one example (28). Within the Nanoviridae, the importance of life stage on vector transmission was only studied in detail by Franz et al. (6), who found that aphid nymphs transmitted Faba bean necrotic yellow virus (FBNYV) more efficiently than adults. Similarly, Magee (17) noted that adult $P$. nigronervosa were poor vectors of BBTV compared to nymphs; however, no results were presented supporting that conclusion. Other studies on BBTV transmission were conducted using groups of individuals without discrimination of life stage, or if noted, a combination of life stages were used for different components of those studies $(11,16,17,27,30)$. Therefore, the effect of $P$. nigronervosa life stage on transmission of BBTV to banana remains unclear.

The transmission efficiency of many vector-borne plant viruses has been show to be affected by temperature $(15,24,26,29)$. Temperature has also been demonstrated to have an impact on BBTD symptom development $(16,27,30)$, spread $(1,23)$, transmission efficiency (30), and on vector biology (22). Wu and $\mathrm{Su}$ (30) compared BBTV acquisition efficiency at 16,20 , and $27^{\circ} \mathrm{C}$ using groups of aphids for transmission experiments, demonstrating that temperature affected efficiency, with no transmission at $16^{\circ} \mathrm{C}$ and maximum efficiency at $27^{\circ} \mathrm{C}$. BBTD symptoms have been estimated to take 3 weeks to 4 months after inoculation to be observed, since most of this variability is suggested to be due to temperature, epidemics can potentially increase in size and spread faster with temperature increments (1). Thus, temperature is likely an important variable on BBTV epidemiology.

We determined the effect of temperature and aphid life stage on BBTV transmission efficiency and how increments of plant access periods for virus acquisition and inoculation impacted trans- 
mission efficiency by individual adult aphids. We also determined if BBTV transmission requires a latent period within vectors. This study highlights the importance of understanding transmission biology and ecology of aphid-borne viruses, especially for relatively poorly studied systems such as those in the family Nanoviridae.

\section{MATERIALS AND METHODS}

Aphids, banana plants, and virus. We used insects from a colony of $P$. nigronervosa maintained at the University of Hawaii at Manoa (22). Insects were reared on tissue cultured banana plants within aphid proof boxes $(60 \mathrm{~cm} \times 60 \mathrm{~cm} \times 60 \mathrm{~cm})$ covered on all sides with Plexiglas except the bottom, which was made of wood. We kept colonies inside a climate controlled insect rearing room with temperatures of $25^{\circ} \mathrm{C} \pm 5^{\circ} \mathrm{C}, 12 \mathrm{~h}$ photoperiod, and a mixture of natural and artificial light. We replaced plants as they outgrew the boxes or became covered in honeydew. For the experiment using different life stages, we compared third instar aphids with apterous adults. Adult aphids were easily recognized by the development of black coloration on their legs. Third instars were identified by size as compared with other instars. All aphids were transferred using a water moistened No. 2 camel hair paintbrush. Banana plants used were Musa sp. AAA (Cavendish subgroup, 'Williams'). We used banana tissue culturing protocols as described previously to grow plantlets (22). Prior to BBTV inoculation plants were kept in an aphid-free greenhouse with natural sunlight maintained at $\approx 27^{\circ} \mathrm{C}$. Healthy banana plants at the five-leaf stage were used as test plants for all experiments. An isolate of BBTV was collected from the Hawi area of the Big Island of Hawaii (North region of the island) in July of 2005. We maintained this isolate in the laboratory through infective aphid transfers onto new tissue-cultured banana plants. These BBTV source plants were kept in an isolated, aphid-free windowless room with artificial growth lights (photoperiod 12:12 L:D) at $30^{\circ} \mathrm{C} \pm 5$. For aphid BBTV inoculation tests, we covered plants with transparent fabric cages with a mesh size of $36 \mathrm{~cm}^{-1}$ (Super Poly Organza, Hyman Hendler and Sons, Los Angeles, CA) and secured at the bottom with a rubber band to prevent aphid escape. At the completion of inoculation access periods (IAP) all plants were treated with the fast acting insecticide acephate (Orthenex, Ortho, Marysville, $\mathrm{OH}$ ) and placed in an insect-free windowless room with artificial growth lights (photoperiod 12:12 L:D) at $30^{\circ} \mathrm{C} \pm 5$ for up to 2 months for symptom development. All acquisition and inoculation experiments took place within temperature controlled diurnal illuminator incubators (VWR International, OR). We set these chambers at three temperatures (20, 25 , and $30^{\circ} \mathrm{C} \pm 0.5^{\circ} \mathrm{C}$ fluctuation) and $12 \mathrm{~h} \mathrm{L:D}$. The temperatures and photoperiod were selected based on environmental conditions in tropical areas where banana is grown.

BBTV detection. We used PCR to verify that plants were BBTV-positive after the completion of each experiment. All plants were tested, regardless of presence or absence of visual symptoms. DNA extraction was performed on small disks of banana leaf tissue that were ground up and extracted with a Qiagen DNeasy kit (Valencia, CA). A flame-sterilized paper holepuncher, $6 \mathrm{~mm}$ in size, was used to collect the plant material. We aligned sequences of BBTV's DNA-1 component (mRep) obtained in GenBank to design a primer set to amplify an 815-bp fragment of that component. Primers used were DNA1f (5'GGCGCGATATGTGGTAGC-3') and DNA 1r (5'-CCTTCGGAAGGAAGTTAGCC- $3^{\prime}$ ). We used 30 cycles of $1 \mathrm{~min}$ at $94^{\circ} \mathrm{C}$, $1 \mathrm{~min}$ at $60^{\circ} \mathrm{C}, 1 \mathrm{~min}$ at $72^{\circ} \mathrm{C}$, and an additional elongation period of $5 \mathrm{~min}$ at $72^{\circ} \mathrm{C}$ to amplify the fragment using PCR. Standard gel electrophoresis, staining, and visualization protocols were used for detection of amplicons.

BBTV acquisition from plant cuttings. $P$. nigronervosa is often found between sheaths of banana leaves, which are areas with difficult access $(16,22)$. To reduce the time required to handle insects during transmission experiments, we conducted a preliminary test to determine if leaf tissue cuttings from source plants could act as a source material for BBTV acquisition by $P$. nigronervosa at different life stages. We quantified if there was any difference in transmission efficiency by nymphs and adults using cut leaf sections from symptomatic BBTV-positive plants for acquisition instead of whole plants. We cut tissue samples (13 cm in length) from the most recently unfurled symptomatic leaf of infected plants maintained in a greenhouse, keeping the middle rib intact, and placed those into two 15 -cm-diameter petri dishes. Thirty adult aphids and 30 third instar nymphs were placed on leaf samples, the dish sealed with Parafilm to prevent aphids from escaping, and maintained in a growth chamber at $25^{\circ} \mathrm{C}$. In addition, 40 adult and third instar $P$. nigronervosa were transferred onto the source plants from which the leaves were collected for this study. We kept these plants in the same growth chamber as the leaf cuttings. After a 24-h virus acquisition access period (AAP), insects were individually transferred for a 24-h IAP on healthy plantlets. This was repeated 20 times for both nymphs and adults (i.e., 20 individuals per treatment). Following the IAP, all plants were treated with insecticide and maintained in an insect free room for symptom development and testing by polymerase chain reaction (PCR) 40 days after inoculation. We used the Fisher exact test to analyze the results.

Latent period within aphids. To determine if BBTV transmission requires a latent period within aphids, we used leaf cuttings as BBTV sources as described previously. Adult aphids (120 per plate) were transferred onto these leaves for a 12-h AAP. To determine the latent period threshold for BBTV transmission we used several IAP $(8,16,24,32$, and $40 \mathrm{~h})$ with 10 plants per period, by transferring groups of five insects to test plants immediately after the $12 \mathrm{~h}$ AAP. Every $8 \mathrm{~h}$, we randomly selected 10 plants and removed the aphids from them. Plant access periods were performed in a room without temperature control $\left(25^{\circ} \mathrm{C} \pm\right.$ $5^{\circ} \mathrm{C}$ ). Two replicates of this experiment were conducted. We used a generalized linear model with binomial error distribution to analyze the effect of "insect latent period threshold" on "transmission rate to plants" (4). There was no statistical difference between the replicates; therefore, we pooled them for the analysis.

Effect of temperature and vector life stage on transmission. We compared the transmission efficiency of adult and third instar $P$. nigronervosa at three temperatures $\left(20,25\right.$, and $\left.30^{\circ} \mathrm{C}\right)$. Leaf cuttings from BBTV positive plants were used as virus source for insects. We transferred 50 adult and third instar aphids to cuttings (three cuttings per treatment) for virus acquisition. No temperature conditioning period was used for the insects. One petri dish with adults and another with nymphs were placed in chambers set at 20,25 , and $30^{\circ} \mathrm{C}$ for a 24 -h AAP. After the AAP we individually transferred the insects onto test plants at room temperature. Test plants were covered with aphid-proof cages and returned to the same chamber for a 24-h IAP. Twenty test plants were used per group (10 adults and 10 nymphs) in each chamber. This experiment was repeated twice, with each repetition treated as a statistical replicate. We analyzed the results with a two-way analysis of variance (ANOVA) followed by the Tukey test to compare all treatments (SigmaStat 3.11, Systat Software, Inc.).

Effect of temperature on acquisition and inoculation efficiencies. Experiments were conducted to identify the relative importance of temperature on BBTV acquisition and inoculation efficiency by adult aphids. To determine the effect of temperature on acquisition we varied the temperature during the AAP while keeping it constant for the IAP. We did the inverse to determine the impact of temperature on inoculation (i.e., AAP temperature constant while IAP temperature was variable). To study the effect of temperature on acquisition we placed adults on BBTV-infected leaf cuttings for virus acquisition. There was no insect temperature acclimation period prior to plant access period. We kept 
cuttings in growth chambers set at 20,25 , and $30^{\circ} \mathrm{C}$ for a $24-\mathrm{h}$ AAP, after which we transferred the insects onto test plants (1 aphid per plant/10 plants per temperature during acquisition) for a $24-\mathrm{h}$ IAP in a $25^{\circ} \mathrm{C}$ chamber. Similarly, to determine the effect of temperature on inoculation efficiency we placed aphids on BBTV-positive cuttings for a $24-\mathrm{h}$ AAP at $25^{\circ} \mathrm{C}$, after which we transferred aphids onto healthy plants at 20,25 , and $30^{\circ} \mathrm{C}$ for a 24-h IAP (total of 10 individuals per treatment). This experiment was repeated twice, with each repetition treated as a statistical replicate. We used ANOVA to analyze results, followed by Tukey tests to identify significant differences among treatments (SigmaStat 3.11, Systat Software, Inc.).

Effect of plant access time on transmission efficiency. We determined BBTV transmission efficiency by individual P. nigronervosa adults at $25^{\circ} \mathrm{C}$ by varying the AAP while keeping IAP constant, or by using a constant AAP followed by variable IAP. The constant AAP and IAP were $24 \mathrm{~h}$. We used 0.5, 1, 2, 6, 12, 18 , and $24 \mathrm{~h}$ as the variable IAP and AAP. Ten adult aphids (1 per plant) were tested per plant access period. BBTV-positive leaf cuttings were used for virus acquisition and healthy plantlets for inoculation. We analyzed the results with linear regressions to estimate the relationship between plant access time and the proportion of plants infected.

\section{RESULTS}

Acquisition from leaf cuttings. We found no significant difference in BBTV transmission rates whether acquisition occurred on whole plants or leaf cuttings when comparing nymphs to nymphs or adults to adults. Five out of twenty nymphs were able to transmit the virus with acquisition on either leaf cuttings or whole plants (25\% efficiency). Individual adult aphids transmitted BBTV 17 out of 20 times when acquisition occurred on whole plants $(85 \%)$ and 19 out of 20 times when on a leaf cutting $(95 \%)$. Analysis (Fisher exact test) showed that nymphs acquired less efficiently than adults on both leaf cuttings and whole plant $(P<$ 0.001 ), and that plant material used for acquisition had no significant effect on BBTV transmission $(P=1.0)$. Therefore, the use of leaf cuttings as sources of BBTV for aphid transmission experiments does not seem to affect plant infection rates when compared to acquisition of the virus from whole plants.

Latent period within aphids. We found that time after the beginning of aphid BBTV acquisition from leaf cuttings had a significant effect on transmission rates $\left(\mathrm{z}_{2,98}=5.127, P<0.0001\right)$.

TABLE 1. Latent period required for Banana bunchy top virus (BBTV) transmission to banana by adult Pentalonia nigronervosa

\begin{tabular}{lc}
\hline Latent period (hours) $^{\mathrm{a}}$ & Transmission rate $^{\mathrm{b}}$ \\
\hline 20 & $0 / 20$ \\
28 & $11 / 20$ \\
36 & $19 / 20$ \\
44 & $17 / 20$ \\
52 & $19 / 20$ \\
\hline
\end{tabular}

a Sum of plant access periods on BBTV infected sources $(12 \mathrm{~h})$ and test plants (successive $8 \mathrm{~h}$ periods).

b Total number of infected plants/tested plants.

TABLE 2. Summary of two-way analysis of variance for experiment testing the effect of temperature and life stage on Banana bunchy top virus transmission to banana by individual Pentalonia nigronervosa

\begin{tabular}{lrrrrr}
\hline Source of variation & df & \multicolumn{1}{c}{ SS } & \multicolumn{1}{c}{ MS } & \multicolumn{1}{c}{$F$} & \multicolumn{1}{c}{$P$} \\
\hline Temperature & 2 & $2,360.667$ & $1,180.333$ & 11.031 & 0.010 \\
Life stage & 1 & $6,440.333$ & $6,440.333$ & 60.190 & $<0.001$ \\
Temperature $\times$ life stage & 2 & 880.667 & 440.333 & 4.115 & 0.075 \\
Residual & 6 & 642.000 & 107.000 & & \\
Total & 11 & $10,323.667$ & 938.515 & & \\
\hline
\end{tabular}

P. nigronervosa failed to inoculate BBTV to test plants until $20 \mathrm{~h}$ after the beginning of the AAP, with transmission efficiency increasing with longer periods ranging from 55 (20 to $28 \mathrm{~h}$ ) to $95 \%$ (28 to $36 \mathrm{~h}$ or longer) (Table 1 ). Therefore, BBTV requires, under the conditions of this experiment, a minimum latent period of $20 \mathrm{~h}$ for aphid transmission.

Effect of temperature and vector life stage on transmission. A significant effect of temperature $(P=0.01)$ and vector life stage $(P<0.001)$ on BBTV transmission to plants was observed, but no interaction between temperature and life stage was found (Table 2). Our results showed that individual adult $P$. nigronervosa were more efficient in transmitting BBTV than nymphs at all three temperatures tested $(P<0.05$, Fig. 1$)$. Adults transmitted the virus more efficiently at 25 and $30^{\circ} \mathrm{C}$ than at $20^{\circ} \mathrm{C}$ (Fig. 1). Overall, nymphs showed a similar trend in transmission rates in relation to temperature compared with adults, although treatments were not statistically different. In that case, we predict that the low transmission rates by nymphs in all treatments reduced the sensitivity of the analysis and that a larger sample size would statistically demonstrate the presence of an effect of temperature on BBTV transmission by nymphs. Nevertheless, the results indicate that vector life stage and temperature have an impact on the efficiency with which $P$. nigronervosa transmits BBTV.

Effect of temperature on acquisition and inoculation efficiencies. When the effect of temperature on acquisition and inoculation was decoupled, we found that both plant access periods impacted transmission efficiency significantly $(P<0.001$, Table 3). Interestingly, temperature affected virus inoculation more dramatically than acquisition (Fig. 2). For example, BBTV acquisition at 20 and $25^{\circ} \mathrm{C}$ had similar efficiency, while inoculation rates at those temperatures were statistically different $(P<$ 0.05). Although transmission rates at constant 25 and $30^{\circ} \mathrm{C}$ were similar (Fig. 1), we found that both acquisition and inoculation efficiencies at $30^{\circ} \mathrm{C}$ (determined independently) were lower than at $25^{\circ} \mathrm{C}(P<0.05$, Fig. 2). When the independent effect of temperature on acquisition and inoculation efficiencies were combined ("acquisition" multiplied by "inoculation" efficiencies at the same temperature), the overall transmission efficiency was found to be similar to the results for BBTV transmission by adults

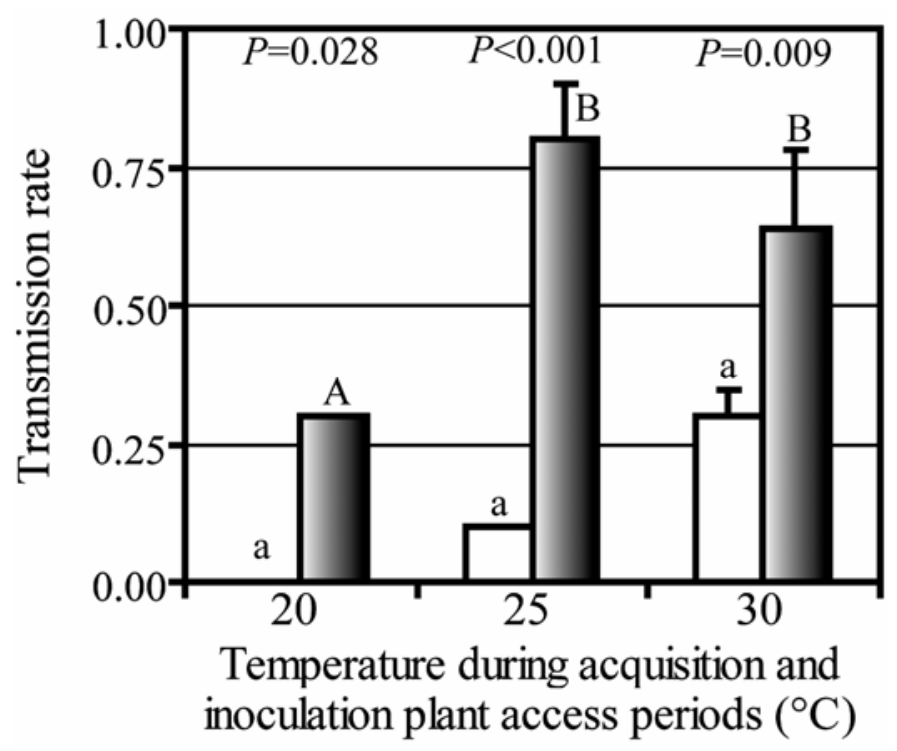

Fig. 1. Banana bunchy top virus transmission rates by individual Pentalonia nigronervosa nymphs (third instar, empty bars) and adults (filled bars) at three different temperatures. Different letters above error bars indicate statistical differences (Tukey test, $P<0.05$ ) for transmission rates at variable temperatures for each life stage (small font for nymphs, capitals for adults). $P$ values above bars show results of pairwise comparisons between transmission rates by nymphs and adults at each temperature (Tukey test). 
observed at constant temperature (Fig. 3). The only exception occurred at $30^{\circ} \mathrm{C}$, where standard plant access periods done at $25^{\circ} \mathrm{C}$ may have reduced overall efficiency in relation to tests done at constant temperatures for both acquisition and inoculation.

Effect of plant access time on transmission efficiency. Transmission efficiency of BBTV by individual $P$. nigronervosa adults at $25^{\circ} \mathrm{C}$ increased with longer AAP and IAP $(P<0.01$, Fig. 4$)$. Acquisition was only observed after a 6-h AAP, but efficiency quickly increased and was similar to inoculation efficiency after the 12-h plant access period. Acquisition and inoculation rates peaked at $18 \mathrm{~h}$ of AAP and IAP using single adult aphids, with transmission efficiency reaching $90 \%$ at that time. As with other systems, the regression for acquisition of BBTV over time had a similar slope to that of inoculation.

\section{DISCUSSION}

Our work shows that BBTV transmission by $P$. nigronervosa is dependent on vector life stage, plant access time, and temperature. We also determined that BBTV transmission requires a latent period within vectors. Temporal characteristics of BBTV acquisition, inoculation, and retention suggest that $P$. nigronervosa transmits this virus in a circulative manner $(6,9,11)$. To our knowledge, Franz et al. (6) were the only authors to have studied the latent period of a nanovirus (FBNYV); however, they estimated the time necessary for $50 \%$ of a population of vectors to

TABLE 3. Summary of two-way analysis of variance for experiment testing the effect of temperature on Banana bunchy top virus acquisition and inoculation efficiencies by individual Pentalonia nigronervosa adults

\begin{tabular}{lrcccr}
\hline Source of variation & df & SS & MS & $F$ & $P$ \\
\hline Temperature & 2 & 0.302 & 0.151 & 36.200 & $<0.001$ \\
AAP/IAP & 1 & 0.367 & 0.367 & 88.200 & $<0.001$ \\
Temperature $\times($ AAP/IAP) & 2 & 0.195 & 0.097 & 23.400 & 0.001 \\
Residual & 6 & 0.025 & 0.004 & & \\
Total & 11 & 0.889 & 0.080 & &
\end{tabular}

a Acquisition access period (AAP), inoculation access period (IAP).

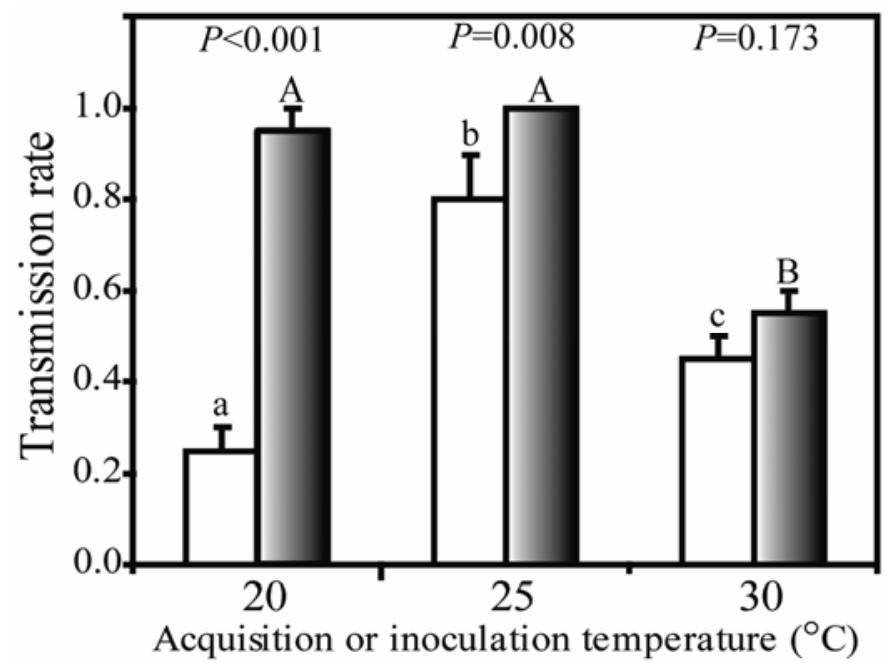

Fig. 2. Effect of temperature on Banana bunchy top virus acquisition and inoculation efficiencies at three different temperatures by individual adult Pentalonia nigronervosa. Empty bars represent transmission efficiency with acquisition access period at $25^{\circ} \mathrm{C}$ followed by an inoculation access period at variable temperatures. Filled bars show transmission rates when the acquisition access period occurred at variable temperatures, with subsequent inoculation access period at $25^{\circ} \mathrm{C}$. Different letters above error bars indicate statistical differences (Tukey test, $P<0.05$ ) for transmission rates at variable temperatures during acquisition or inoculation access periods. $P$ values above bars show results of pairwise comparisons between acquisition and inoculation rates at each temperature (Tukey test). transmit the virus, rather than the requirement of a latent period. Our results indicate that the latent period of BBTV is similar to that of other aphid-borne circulative, nonpropagative viruses, such as Potato leaf roll virus (PLRV) and Barley yellow dwarf virus (BYDV) in the family Luteoviridae $(9,29)$ and Pea enation mosaic virus (PEMV, 3). The presence of a required latent period for BBTV transmission is further indication that nanoviruses are circulative viruses (18). More research on the biotic and abiotic

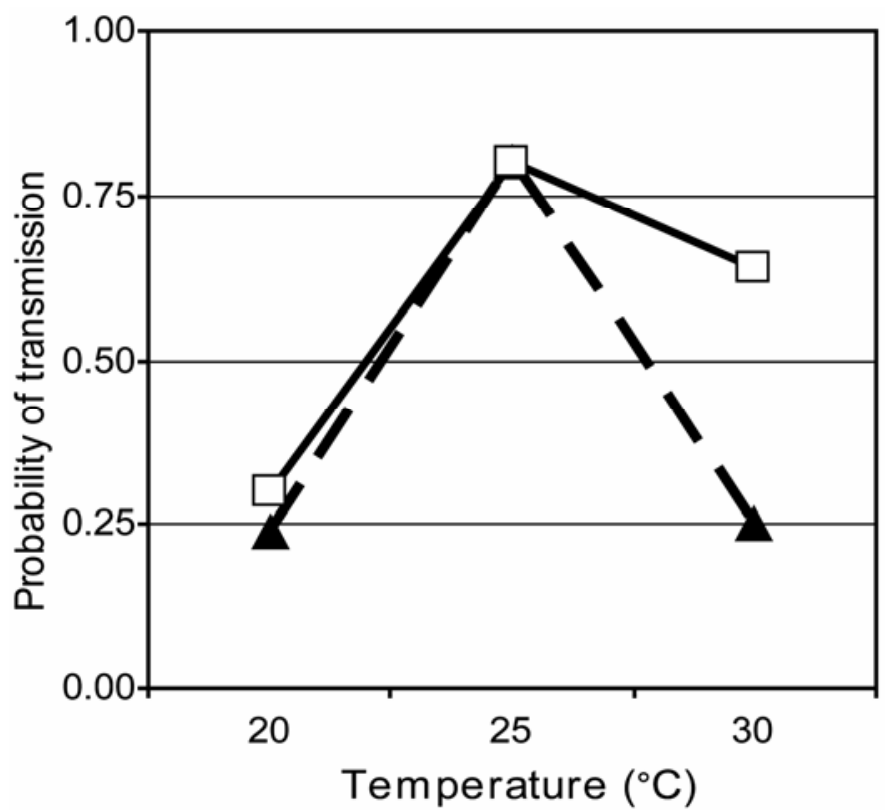

Fig. 3. Dashed line (filled triangles) shows the combined effect of acquisition and inoculation on overall transmission when those variables were independently quantified (rates obtained for acquisition and inoculation at different temperatures were multiplied). Solid line (empty squares) represents the same data shown in Figure 1 for Banana bunchy top virus transmission by adult aphids with acquisition and inoculation done at the same temperatures.

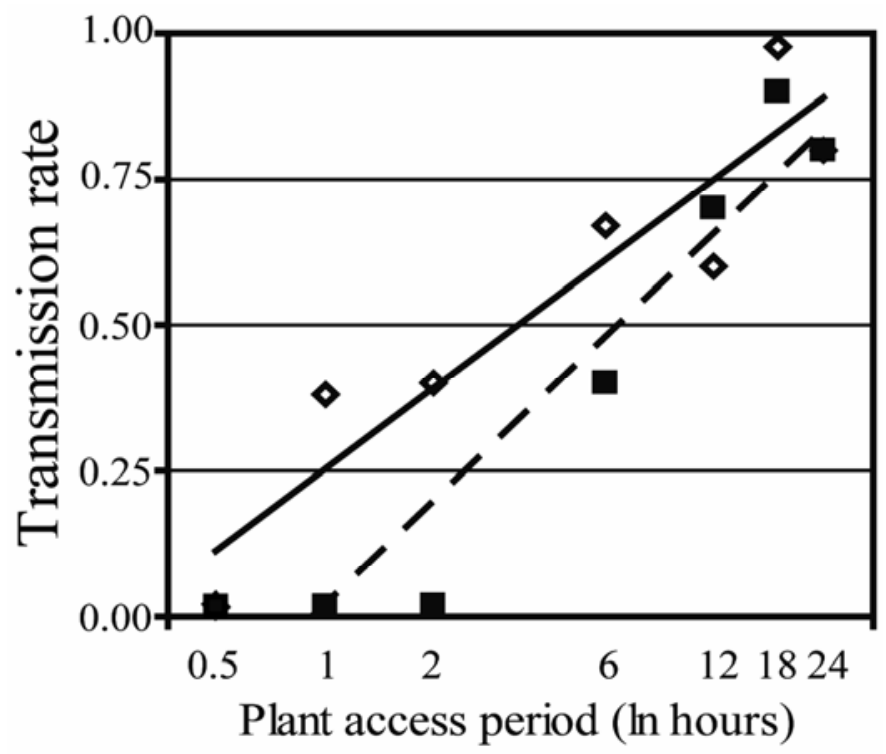

Fig. 4. Effect of time on transmission efficiency of Banana bunchy top virus to banana by individual adult Pentalonia nigronervosa. Filled squares (dashed line) represent transmission rates for variable acquisition access periods followed by a 24-h inoculation access period on test plants $(y=0.2562 x+$ $0.0213, r^{2}=0.905, P<0.001$ ); empty diamonds (solid line) represent data for the effect of aphid inoculation plant access time on transmission efficiency after a 24-h acquisition access period $\left(y=0.2007 x+0.2534, r^{2}=0.856, P=\right.$ $0.003)$. 
factors affecting the latent period of BBTV and other nanoviruses is necessary; vector life stage, temperature, and other variables may impact transmission rates, as shown for other circulative viruses $(3,29)$.

Vector life stage is an important factor for the transmission of many insect-borne plant viruses (18). Within the family Nanoviridae, aphid nymphs have been shown to transmit FBNYV more efficiently than adults (6). Magee (17) noted that $P$. nigronervosa nymphs were more efficient vectors of BBTV than adults, but did not present the results of his work. Our experiments showed that $P$. nigronervosa third instar nymphs were less efficient vectors of BBTV compared with adults. Factors that may address the differences between this work and that of Magee (17) include virus strain and vector biotype used. It has been proposed that the membrane barriers of aphid gut and accessory salivary gland membranes are largely responsible for the specificity of circulative viruses (9), therefore intraspecific physiological differences in these membrane barriers of adult and nymphal $P$. nigronervosa may account for the difference in transmission efficiency observed, assuming that the pathway of virus circulation for nanoviruses is similar to luteoviruses.

Temperature has been shown to affect the transmission of circulative viruses $(15,26)$, including BBTV (30). The upper and lower temperature thresholds used here reflect most tropical areas where banana is grown. These experiments showed that transmission rates were significantly higher at 25 and $30^{\circ} \mathrm{C}$ than at $20^{\circ} \mathrm{C}$. Temperature had a similar effect on the biology of $P$. nigronervosa (22), with greater aphid fecundity at $25^{\circ} \mathrm{C}$, suggesting that biological factors, such as aphid feeding behavior, or response to heat, may have been of importance in determining the transmission rates observed. We did not test the impact of temperature on the length of the latent period, but we hypothesize it will be slower at $20^{\circ} \mathrm{C}$ than at $25^{\circ} \mathrm{C}(29)$. The requirement of a latent period for BBTV transmission may have underestimated transmission rates observed at $20^{\circ} \mathrm{C}$; some aphids may not have transmitted the virus because the latent period for that individual was not over during the plant access periods used in our experiments. As climate changes and temperatures rise in the future (25), BBTV dissemination may be slower in certain tropical areas as aphid vectors will reproduce less and could transmit BBTV with lower efficiency than at current temperatures. Conversely, colder regions with low BBTD prevalence may face more frequent or more severe epidemics under warmer climates. More needs to be understood about the importance of temperature on the acquisition and inoculation, among other factors, of aphid-borne circulative viruses.

Transmission experiments with insect-borne plant pathogens usually measure the combined outcome of acquisition and inoculation probabilities; however, these are separate processes that may be affected differentially by environmental factors. Our results indicate that the decoupled acquisition and inoculation efficiencies at different temperatures were numerically equivalent to experiments done at constant temperatures in estimating the probability of BBTV transmission to plants (Fig. 3). However, BBTV inoculation rate was more temperature-dependent than acquisition. It is likely that aphid feeding and probing behaviors are at least partly responsible for the results observed, as transmission is dependent on vector activities. As mentioned above, we did not study the effect of temperature on latent period, but that should be considered in future studies (29). Understanding why and how different transmission parameters of insect-borne plant pathogens vary in relation to temperature may have epidemiological relevance and should be addressed in more detail.

Because BBTV transmission efficiency over time has never been determined using individual aphids, and due to our findings on the importance of life stage on transmission efficiency, we considered how time impacts transmission by adult aphids. Our results were similar to those of $\mathrm{Hu}$ et al. (11), who used groups of adults or mixed vector life stages to determine a minimum AAP and IAP for BBTV transmission to banana. Extrapolating our results based on the regression equation obtained for individual adult $P$. nigronervosa, BBTV acquisition requires a 1-h AAP, and inoculation can potentially occur with $17 \mathrm{~min}$ of plant access period. It is often the case for similar transmission studies that regressions for inoculation and acquisition rates have similar slopes, but that inoculation rates are higher than acquisition with short plant access periods (21). This can be attributed to the time required for the insect to reach phloem cells, which is assumed to be equal for both events, and the opportunity of inoculating a susceptible cell versus probing into an infected cell and acquiring a sufficiently large virus titer for transmission. Importantly, the proportion of infected plants in our study did not increase with plant access periods longer than $18 \mathrm{~h}$, suggesting that $24-\mathrm{h}$ acquisition and inoculation plant access periods are sufficient to reach optimal transmission efficiency. The effect of time on acquisition and inoculation rates has been studied for luteoviruses $(10,14,20)$, with efficiency peaking within $24 \mathrm{~h}$ of plant access period, similar to the circulative nanoviruses FBNYV (6) and BBTV.

Aphid transmission of nonpropagative, circulative viruses seems to be impacted by similar biotic and abiotic factors, independent of plant virus taxonomy. Vector life stage affects the transmission of PEMV, luteoviruses, and nanoviruses $(3,6,9)$. However, there is variability in these relationships, such as in the case of nanoviruses, which have a different effect of life stage on FBNYV and BBTV transmission. Time spent by vectors on plants is also important, with transmission efficiency increasing up to 24 $\mathrm{h}$ after the beginning of plant access periods $(6,10,11,14,15,20)$. Such generalizations and differences are useful in classifying insect-borne plant viruses based on transmission biology, permitting researchers to infer biological characteristics of these associations and the impact of possible management strategies or their respective feasibilities (18). However, studies are necessary for each disease due to variability within individual systems $(3,29)$ and potential exceptions to these broad generalizations.

Our results show that temperature, vector life stage, and plant access period affect aphid vector transmission of BBTV. Temperature also impacted virus acquisition and inoculation to plants when those factors were analyzed independently. We demonstrate that BBTV transmission requires a latent period within insects after acquisition. The experiments conducted highlight the complexity and relevance of biotic and abiotic parameters on the transmission of nanoviruses. Our results emphasize the need to conduct such studies for aphid-borne circulative viruses, as generalizations based on one system may not apply to another (e.g., effect of vector life stage on transmission of BBTV and FBNYV).

\section{ACKNOWLEDGMENTS}

We thank C. Hooks and M. Wright for discussions and suggestions, and colleagues in our laboratory for comments on the manuscript. This work was supported by grants from the USDA-CSREES (WSARE SW04-064, TSTAR 2004-34135-14976), and USDA-ARS (PBARC 5853204-534). This research was part of M. D. Anhalt's MS thesis.

\section{LITERATURE CITED}

1. Allen, R. N. 1978. Spread of bunchy top disease in established banana plantations. Aust. J. Agric. Res. 29:1223-1233.

2. Bell, K. E., Dale, J. L., Ha, C. V., Vu, M. T., and Revill, P. A. 2002. Characterization of rep-encoding components associated with banana bunchy top nanovirus in Vietnam. Arch. Virol. 147:695-707.

3. Chapman, R. K., and Bath, J. E. 1968. The latent period of pea enation mosaic virus in three of its aphid vectors with emphasis on adult versus nymph comparisons. Phytopathology 58:494-499.

4. Crawley, M. J. 2002. Statistical Computing: An Introduction to Data Analysis Using S-Plus. John Wiley \& Sons Ltd., Chichester, UK.

5. Dale, J. L. 1987. Banana bunchy top: An economically important tropical plant virus disease. Adv. Virus Res. 33:301-325. 
6. Franz, A., Makkouk, K. M., and Vetten, H. J. 1998. Acquisition, retention and transmission of Faba bean necrotic yellows virus by two of its aphid vectors, Aphis craccivora (Koch) and Acyrthosiphon pisum (Harris). J. Phytopathol. 146:347-355.

7. Franz, A. W. E., van der Wilk, F., Verbeek, M., Dullemans, A. M., and van den Heuvel, J. F. J. M. 1999. Faba bean necrotic yellows virus (Genus Nanovirus) requires a helper factor for its aphid transmission. Virology 262:210-219

8. Fauquet, C. M., Mayo, M. A., Maniloff, J., Desselberger, U., and Ball, L. A. 2005. Virus Taxonomy. Classification and Nomenclature of Viruses. Elsevier Academic Press, San Diego, CA.

9. Gray, S. M., and Gildow, F.E. 2003. Luteovirus-aphid interactions. Annu. Rev. Phytopathol. 41:539-566.

10. Gray, S. M., Power, A. G., Smith, D. M., Seaman, A. J., and Altman, N. S. 1991. Aphid transmission of barley yellow dwarf virus: Acquisition access periods and virus concentration requirements. Phytopathology 81:539-545.

11. Hu, J. S., Wang, M., Sether, D., Xie, W., and Leonhardt, K. W. 1996. Use of polymerase chain reaction (PCR) to study transmission of banana bunchy top virus by the banana aphid (Pentalonia nigronervosa). Ann. Appl. Biol. 128:55-64.

12. Hull, R. 2002. Matthews' Plant Virology, 4th ed. Academic Press, New York.

13. Julia, J. F. 1982. Myndus taffini (Homoptera Cixiidae), vecteur du dépérissement foliaire des cocotiers au Vanuatu. Oléagineux 37:409-414.

14. Leonard, S. H., and Holbrook, F. R. 1978. Minimum acquisition and transmission times for potato leaf roll virus by the green peach aphid. Ann. Entomol. Soc. Am. 71:493-495.

15. Lowles, A. J., Tatchell, G. M., Harrington, R., and Clark, S. J. 1996. The effect of temperature and inoculation access period on the transmission of barley yellow dwarf virus by Rhopalosiphum padi (L.) and Sitobion avenae (F.). Ann. Appl. Biol. 128:45-53.

16. Magee, C. J. P. 1927. Investigation on the bunchy top disease of the banana. Page 86. Council for Scientific and Industrial Research, Melbourne.

17. Magee, C. J. P. 1940. Transmission studies on the banana bunchy-top virus. J. Aust. I. Agric. Sci. 6:109-110.
18. Nault, L. R. 1997. Arthropod transmission of plant viruses: A new synthesis. Ann. Entomol. Soc. Am. 90:521-541.

19. Ng, J. C. K., and Perry, K. L. 2004. Transmission of plant viruses by aphid vectors. Mol. Plant Pathol. 5:505-511.

20. Power, A. G., Seaman, A. J., and Gray, S. M. 1991. Aphid transmission of barley yellow dwarf virus: Inoculation access periods and epidemiological implications. Phytopathology 81:545-548.

21. Purcell, A. H., and Finlay, A. H. 1979. Evidence for noncirculative transmission of Pierce's disease bacterium by sharpshooter leafhoppers. Phytopathology 69:393-395.

22. Robson, J. D., Wright, M. G., and Almeida, R. P. P. 2007. Biology of Pentalonia nigronervosa (Hemiptera, Aphididae) on banana using different rearing methods. Environ. Entomol. 36:46-52.

23. Smith, M. C., Kenyton, J. H., and Foot, L. C. 1998. Quantitative epidemiology of Banana Bunchy Top Virus Disease and its control. Plant Pathol. 47:177-187.

24. Sylvester, S. E. 1980. Circulative and propagative virus transmission by aphids. Annu. Rev. Entomol. 25:257-286.

25. Rahmstorf, S., Cazenave, A., Church, J. A., Hansen, J. E., Keeling, R. F., Parker, D. E., and Somerville, R. C. J. 2007. Recent climate observations compared to projections. Science 316:709.

26. Smyrnioudis, I. N., Harrington, R., Hall, M., Katis, N., and Clark, S. J. 2001. The effect of temperature on variation in transmission of a BYDV PAV-like isolate by clones of Rhopalosiphum padi and Sitobion avenae. Eur. J. Plant Pathol. 107:167-173.

27. Sun, S. K. 1961. Studies on the bunchy-top disease of banana. Special Publication College of Agriculture, National Taiwan University 10:82109.

28. van de Wetering, F., Goldbach, R., and Peters, D. 1996. Tomato spotted wilt tospovirus ingestion by first instar larvae of Frankliniella occidentalis is a prerequisite for transmission. Phytopathology 86:900-905.

29. van der Broek, L. J., and Gill, C. C. 1980. The median latent periods for three isolates of barley yellow dwarf virus in aphid vectors. Phytopathology 70:644-666.

30. Wu, R. Y., and Su, H. J. 1990. Transmission of banana bunchy top virus by aphids to banana plantlets from tissue culture. Bot. Bull. Acad. Sinica 31:7-10. 